\title{
The first record of the Siberian northern shrike (Lanius borealis sibiricus) in Lithuania with molecular confirmation
}

\author{
Vytautas Eigirdas ${ }^{1^{*}}$, \\ Vesta Jonik $\dot{e}^{2}$ \\ ${ }^{1}$ Tadas Ivanauskas Zoological Museum, \\ Ventes Ragas Ornithological Station, \\ Kintai 99361, Lithuania \\ ${ }^{2}$ Vytautas Magnus University, \\ K. Donelaičio g. 58, \\ 44248 Kaunas, Lithuania
}

\begin{abstract}
Climate change significantly affects biological diversity around the world. Trends of this phenomenon have also been noticed in Lithuania: in the past decades, 55 new bird species have been recorded. The recent record of a new species was done on 3 December 2019. During ordinary birds ringing carried out in Ventes Ragas Ornithological Station in Lithuania, an individual Siberian northern shrike (Lanius borealis sibiricus) was caught and ringed. Additional blood sample was collected for species confirmation. Based on identification keys and molecular mitochondrial cytochrome b analysis, we report that this is the first record of the Siberian northern shrike in Lithuania.
\end{abstract}

Keywords: Siberian northern shrike, Lanius borealis sibiricus, Lithuania, first record

\section{INTRODUCTION}

In the past decades, 55 new bird species have been recorded in Lithuania territory (Jusys et al., 2017). Some of them were introduced by humans (Keller et al., 2011; Pârâu et al., 2016), and others, such as the rosy starling (Pastor roseus) and the red-rumped swallow (Cecropis daurica) (Jusys et al., 2017) were recorded due to changes in bird migration routes. Bird migration is a very complicated phenomenon that could be affected by a considerable number of factors (Newton, 2008; Žalakevičius, 2015). One of those could be the climate change, which has been observed

\footnotetext{
* Corresponding author. Email: v.eigirdas@gmail.com
}

around the world (Marquet et al., 2019; Jetz et al., 2019). Without exception, warmer winters and springs have also been observed in Lithuania (Bukantis, Rimkus, 2005; Rimkus et al., 2018). For this reason, a lot of local bird breeding sites have moved in the north-eastern direction (Žalakevičius, 2015). The aim of this paper is to describe the first ringing record of the Siberian northern shrike (Lanius borealis sibiricus) in Lithuania.

\section{MATERIALS AND METHODS}

One first-year Siberian northern shrike was captured and ringed at the end of autumn migration at Ventès Ragas Ornithological Station, Lithuania $(55.34 \mathrm{~N}, 21.19 \mathrm{E})$ on 3 December 2019 at 
10:30 am. The shrike was caught with a mist net (mesh size $30 \times 30 \mathrm{~mm}$, height $2.5 \mathrm{~m}$, length $18 \mathrm{~m}$ ) in the bushes near the Curonian lagoon. The bird was identified using Shirihai and Svensson's (2018) key identification criteria. In addition, the bird was weighed and its wing, tail, and bill to feathers length measurements were done. The bird was ringed with a metal ring No. KE06803 of the Lithuanian Bird Ringing Centre. A blood sample was collected from the brachial vein using a fine $(28 \mathrm{G})$ needle and $70 \mu$ l Fisherbrand ${ }^{\mathrm{m}}$ Color-Coded Capillary tube (Thermo Fisher Scientific, Lithuania). The shrike was released into the wild after ringing and examination.

DNA was extracted from the blood sample using Genomic DNA Purification Kit (Thermo Fisher Scientific, Lithuania) following the manufacturer's instruction. For molecular species identification, L14990 and H16065 primers that amplify approximately 1000-bp fragment of mitochondrial cytochrome $b$ gene were used in PCR, as previously described (Hackett, 1996). Reaction volume of $25 \mu$ contained $1 \times$ MyTaq Buffer (Bioline, UK), 10 pmol of each primer, $1 \mathrm{U}$ of MyTaq DNA polymerase (Bioline, UK), and $2 \mu \mathrm{l}$ of DNA from the shrike blood sample.
The amplification programme comprised $94^{\circ} \mathrm{C}$ for $5 \mathrm{~min}$, followed by $94^{\circ} \mathrm{C}$ for $1 \mathrm{~min}, 52^{\circ} \mathrm{C}$ for $1 \mathrm{~min}, 72^{\circ} \mathrm{C}$ for $1 \mathrm{~min}$ in 35 cycles, and a final extension at $72^{\circ} \mathrm{C}$ for $5 \mathrm{~min}$. In all runs, positive and negative controls were used.

The PCR products were extracted from agarose gel purified using the GenJet PCR Purification Kit (Thermo Fisher Scientific, Lithuania), and then sequenced (Macrogen Europe B. V., Netherlands). Sequence analysis was performed using Mega X software (Kumar et al., 2018) and aligned with the Muscle algorithm. The evolutionary history was inferred by the maximum likelihood method and the Hasegawa-KishinoYano (HKY) model using a discrete Gamma distribution $(+G)$ and bootstrap analysis of 1000 replicates. The most appropriate model of nucleotide substitution was determined according to the Bayesian information criterion (BIC) using the Model function as implemented in MEGA.

\section{RESULTS AND DISCUSSION}

In size, the bird caught in Lithuania was similar to the great grey shrike (Lanius excubitor), but had a different appearance in comparison with the common grey shrike (Fig. 1).

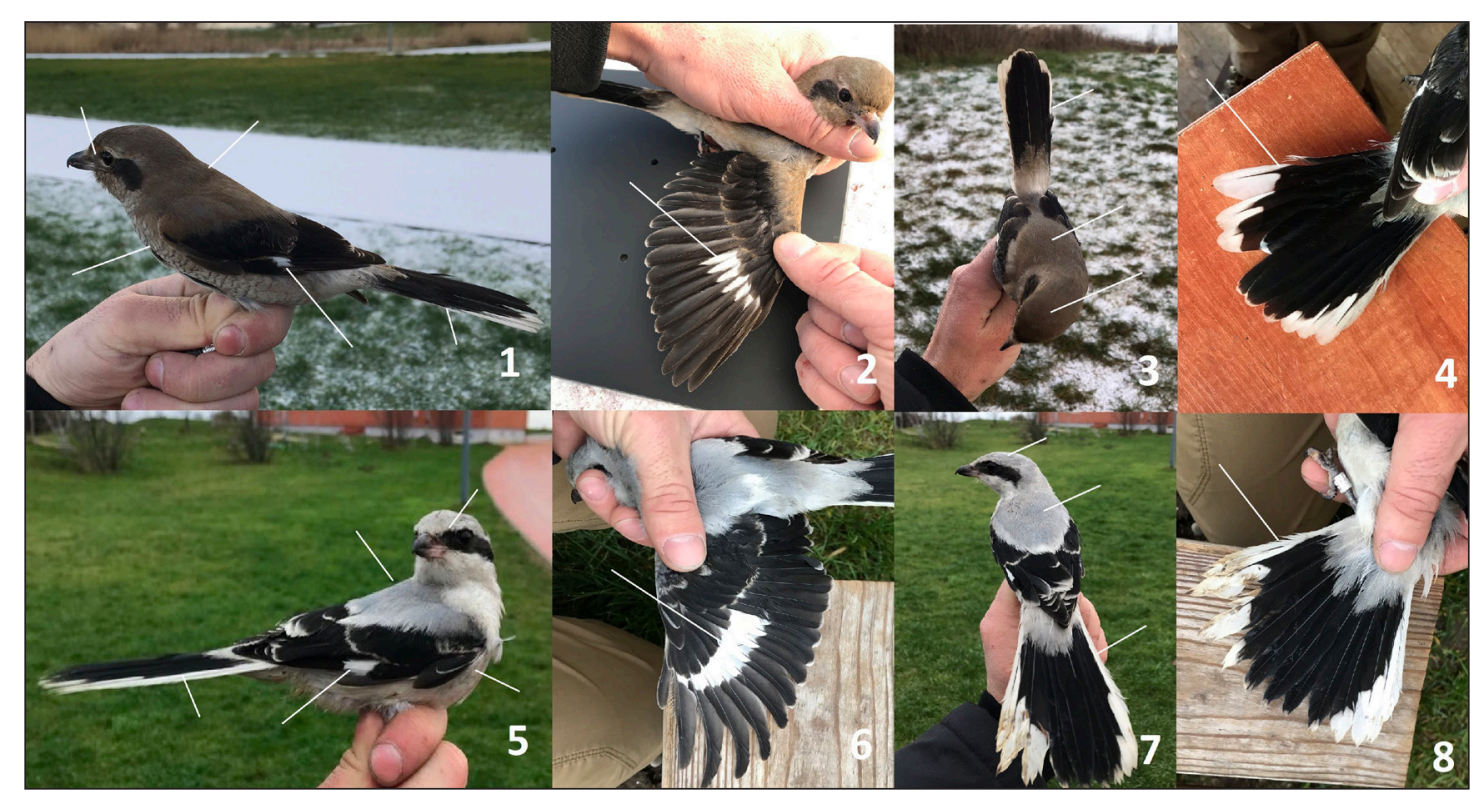

Fig. 1. Comparison of the birds caught in Ventès Ragas Ornithological Station: 1-4 - a Siberian northern shrike (Lanius borealis sibiricus), 3 December 2019; 5-8 - a first-year great grey shrike (Lanius excubitor excubitor), 4 December 2019 
The bird was the size of a small thrush, had a long fan-shaped tail with white edges and blunt wings. The bird had a dark brown mask only behind the eyes and the lores were pale brown. The tail and the wings were dark brown, almost black (Fig. 1.1 and 1.5). The crown, nape, back and the lesser coverts were more of a brown-grey colour than the great grey shrike (Fig. 1.3 and Fig. 1.7). The white wing patch was relatively small and ended on primary coverts. The greater coverts were no longer white (Fig. 1.2 and Fig. 1.6). The tail feathers were also less white in comparison with the grey shrike (Fig. 1.4 and Fig. 1.8). The bird's throat, breast, and belly were of ochre-brown tint and striped across (Fig. 1.1). The measurements of the bird: wing $116 \mathrm{~mm}$, weight $59 \mathrm{~g}$, bill to feathers $18.2 \mathrm{~mm}$, tail $118 \mathrm{~mm}$. All parts in the description are consistent with the identification of the Siberian northern shrike (Lanius borealis sibiricus) as described by Shirihai and Svensson (2018).

The problem of identification of $L$. borealis is related with wide colour polymorphism of L. excubitor, which are common in Europe (Tajkova, Red'kin, 2015). L. excubitor have so many variations in colour (Portenko, 1954; Sotnikov, 2006; Panov, 2008) that European populations were suggested to be divided into three subspecies (Dement'ev, 1954). However, Tajkova and Red'kin (2015) pointed out that L. borealis sibiricus have significant well defining morphological traits.

The nomenclature classification of grey shrikes is very confusing. From the beginning, grey shrikes $L$. excubitor were treated as one species with 20 subspecies distributed over much of the Palaearctic realm, North America, and North Africa (Vaurie, 1959; Rand, 1960). Based on morphological and ecological characteristics and geographical distributions, the grey shrike was divided into two species: the Iberian (or southern) grey shrike (L. meridionalis) and the great (or northern) grey shrike (L. excubitor) (Harris, 2010; del Hoyo et al., 2020). Based on molecular studies, the northern grey shrike was divided into L. excubitor, which is mostly distributed in Europe, and
L. borealis (the distribution covers Asia) (Olsson et al., 2010). Subspecies that are mostly observed in Asia, such as L. b. sibiricus Bogdanov, 1881, L. b. mollis Eversmann, 1853, L. b. funereus Menzbir, 1894, L. b. bianchii E. Hartert, 1907, and its North American form, and L. b. borealis Vieillot, 1808 (Tajkova, Red'kin, 2015; del Hoyo et al., 2020) were assigned to L. borealis.

For correct identification, additional molecular analysis was done to confirm the bird species. The partial sequence of mitochondrial cytochrome b derived from the bird's blood sample was blasted against sequences available in GenBank. The sequence examined in this study showed $99.76-100 \%$ identity with isolates of Lanius borealis sibiricus from South Korea (GU253543, GU253542), Russia (GU253545), and China (GU253541). In the mitochondrial cytochrome $\mathrm{b}$ phylogenetic tree, the isolates clustered together with sequences of $L . b$. sibiricus from GenBank and formed a separate group with other Lanius borealis subspecies (Fig. 2). The partial sequence of mitochondrial cytochrome b gene of L. b. molis and L. b. funereus is missing (no records of our examined gene part in NCBI).

The distribution range for the Siberian northern shrike (L. b. sibiricus) extends in north-eastern Siberia, starting with the Yenisei River eastwards, Trans-Baikal, and the Russian Far East. The Siberian northern shrike can also be found in northern Mongolia. The distribution range includes the tundra and taiga natural areas (Shirihai, Svensson, 2018). For wintering, L. b. sibiricus fly to southern Siberia, Central Asia and are found in north-eastern China, Mongolia, eastern Kazakhstan, and Kyrgyzstan. Moreover, there are records of the Siberian northern shrike from Ukraine and eastern Russia (Tajkova, Red'ken, 2015). Less commonly, the Siberian northern shrike is found in northwestern Europe. This species was recorded in Norway, Finland, Sweden, Germany, and the Netherlands, including record dates from 31 October to 2 March, with a peak in November (Brandsma, 2019; Tarsiger, 2019). However, the records from Finland, Sweden, Germany, 


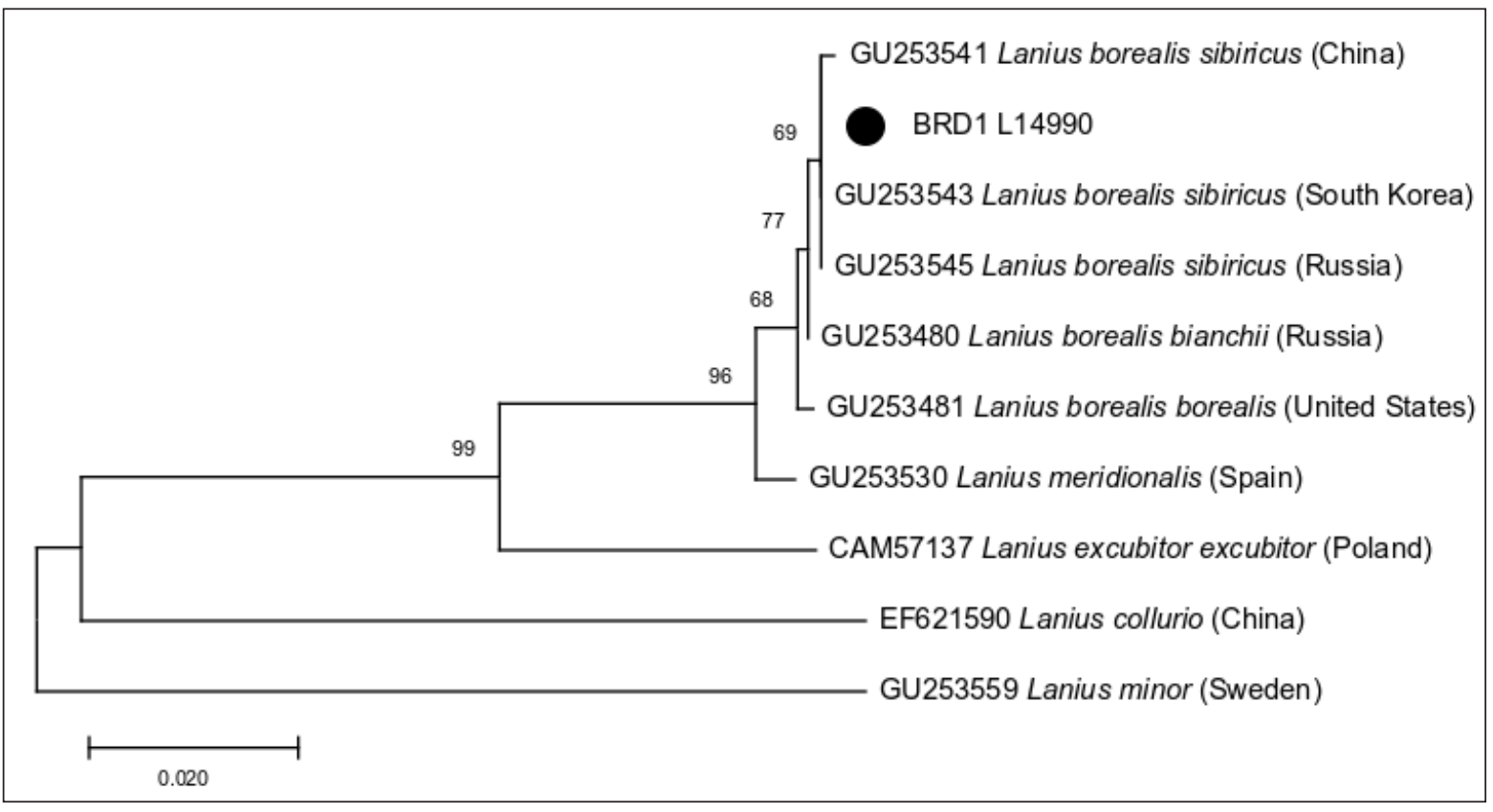

Fig. 2. Maximum likelihood analysis based on partial sequences of the mitochondrial cytochrome b gene of birds. The evolutionary relationships were computed using the HKY model with Gama distribution and bootstrap analysis of 1000 replicates. The Lithuanian sample is marked "•". Two shrike species found in Lithuania (Lanius minor and Lanius collurio) were selected as an outgroup

and the Netherlands were accepted only from photographs and only the birds from Norway that were shot in Hamar in 1881 and 1891 were confirmed by DNA (Brandsma, 2019). Such dispersal in different directions is very natural for northSiberian populations, which are forced to move long distances due to extreme continental climate conditions during the winter period (Tajkova, Red'ken, 2015).

\section{CONCLUSIONS}

To our knowledge, this is the first ringing report of the Siberian northern shrike in Lithuania. Additional studies should be taken to determine whether this record was just accidental or whether Northern Europe is featured in the wintering range of the Siberian northern shrike.

\section{ETHICAL APPROVAL}

All aspects of the study were performed according to the guidelines established for the ethical treatment of animals and comply with current Lithuanian regulations. Bird trapping and blood sample collection were authorized by the Environmental Protection Agency (Reference: 2019-02-28, Nr. 5).

Received 24 June 2020 Accepted 9 July 2020

\section{References}

1. Bukantis A, Rimkus E. Climate variability and change in Lithuania. Acta Zool Lituanica 2005; 15(2): 100-4.

2. Dement'ev GP. Birds of the Soviet Union. Moskva: Sovetskaya Nauka. 1954; 6: 5-57. Russian

3. Hackett SJ. Molecular phylogenetics and biogeography of tanagers in the genus Ramphocelus (Aves). Mol Phylogenet Evol. 1996; 5: $368-82$.

4. Harris T. Shrikes and bush-shrikes: including wood-shrikes, helmet-shrikes, shrike 
flycatchers, philentomas, batises and wattleeyes. A \& C Black, 2010.

5. del Hoyo J, Collar N, Marks JS. Handbook of the birds of the world alive. Barcelona: Lynx Edicions; 2020 [cited 2020 January 18] Available from: https://www.hbw.com/node/1343840 on).

6. Jetz W, McGeoch MA, Guralnick R, Ferrier S, Beck J, Costello MJ, Meyer C. Essential biodiversity variables for mapping and monitoring species populations. Nat Ecol Evol. 2019; 3(4): 539-51.

7. Jusys V, Karalius S, Raudonikis L. New and rare birds for Lithuania. Vilnius: Lietuvos ornitologų draugija; 2017. p. 224. Lithuanian.

8. Keller RP, Geist J, Jeschke JM, Kühn I. Invasive species in Europe: ecology, status, and policy. Environ Sci Eur. 2011; 23(1): 23.

9. Kumar S, Stecher G, Li M, Knyaz C, Tamura K. MEGA X: molecular evolutionary genetics analysis across computing platforms. Mol Biol Evol. 2018; 356: 1547-9.

10. Newton I. The migration ecology of birds. Elsevier Academic Press, UK; 2008: p. 976.

11. Brandsma M., 2019. .Retrieved from: http:// www.martinbrandsma.nl/lanius-borealis-sibiricus-in-western-europe/

12. Marquet PA, Naeem S, Jackson JB, Hodges K. Navigating transformation of biodiversity and climate. Sci Adv. 2019; 5(11): eaba0969.

13. Olsson U, Alström P, Svensson L, Aliabadian M, Sundberg P. The Lanius excubitor (Aves, Passeriformes) conundrum-taxonomic dilemma when molecular and non-molecular data tell different stories. Mol Phylogenet Evol. 2010; 55(2): 347-57.

14. Panov EN: Shrikes (family Laniidae) of the world fauna. Ecology, behavior, evolution.
Moskva: Tovarishchestvo nauchnykh izdanii KMK; 2008. p. 284.

15. Pârâu LG, Strubbe D, Mori E, Menchetti M, Ancillotto L, Kleunen AV, Clergeau P. Roseringed Parakeet Psittacula krameri populations and numbers in Europe: a complete overview. J Ornithol. 2016; 9(1): 1-13.

16. Portenko LA. Birds of the USSR. Moskva: Izdatel'stvo Akademii nauk SSSR; 1954. p. 255.

17. Rand AL. Family Laniidae. In: Mayr E, Greenway JC, Jr., editors. Checklist of the birds of the world, vol. IX. Cambridge, MA: Museum of Comparative Zoology; 1960.

18. Rimkus E, Briede A, Jaagus J, Stonevicius E, Kilpys J, Viru B. Snow-cover regime in Lithuania, Latvia and Estonia and its relationship to climatic and geographical factors in 19612015. Boreal Environ. Res. 2018; 23: 193-208.

19. Shirihai H, Svensson L. Handbook of Western Palearctic Birds, Volume 1: Passerines: Larks to Warblers. Bloomsbury Publishing: 2018; p. 207.

20. Sotnikov VN. Birds of the Kirov Region and adjacent territories. Passeriformes. Vol. 1. Kirov: Triada;. 2006. p. 448.

21. Tarsiger, 2019. Retrieved from: http://www. tarsiger.com/home/index.php?lang=eng.

22. Tajkova SU, Red'kin AA. The Northern Shrike Lanius borealis sibiricus Bogdanov, 1881 (Aves: Laniidae) in Ukraine: a taxonomic assessment. Journal of the National Museum (Prague), Natural History Series. 2014; 183(8): 89-107.

23. Vaurie C. The birds of the Palearctic fauna. Order Passeriformes. London: H. F. and G. Witherby; 1959.

24. Žalakevičius M. Paukščių migracija. Lithuania: Gamtos tyrimų centras; 2015. p. 380. 


\section{Vytautas Eigirdas, Vesta Jonikè}

PIRMASIS LANIUS BOREALIS SIBIRICUS

PRANEŠIMAS LIETUVOJE SU MOLEKULI-

NIU PATVIRTINIMU

\section{Santrauka}

Klimato kaita daro didelę ịtaką biologinei ịvairovei visame pasaulyje. Šio reiškinio tendencijos pastebimos ir Lietuvoje. Per pastaruosius dešimtmečius Lietuvoje buvo užregistruotos 55 naujos paukščių rūšys. Paskutini kartą nauja paukščio rūšis buvo užregistruota $2019 \mathrm{~m}$. gruodžio 3 dieną. Iprasto paukščiu žiedavimo metu Ventes rago ornitologinèje stotyje Lietuvoje buvo pagauta ir sužieduota sibirinè medšarke (Lanius borealis sibiricus). Paukščio identifikavimui buvo paimtas kraujo pavyzdys. Remiantis identifikavimo raktais ir molekuline mitochondriju citochromo b analize, mes teigiame, kad tai yra pirmasis sibirinès medšarkès stebėjimo atvejis Lietuvoje.

Raktažodžiai: medšarke, Lanius borealis sibiricus, Lietuva, nauja rūšis 